\title{
General health and oral health status in elderly dental patients in Isparta, Turkey
}

\author{
E. Bozdemir ${ }^{1}$, H.H. Yilmaz ${ }^{2}$, H. Orhan ${ }^{3}$
}

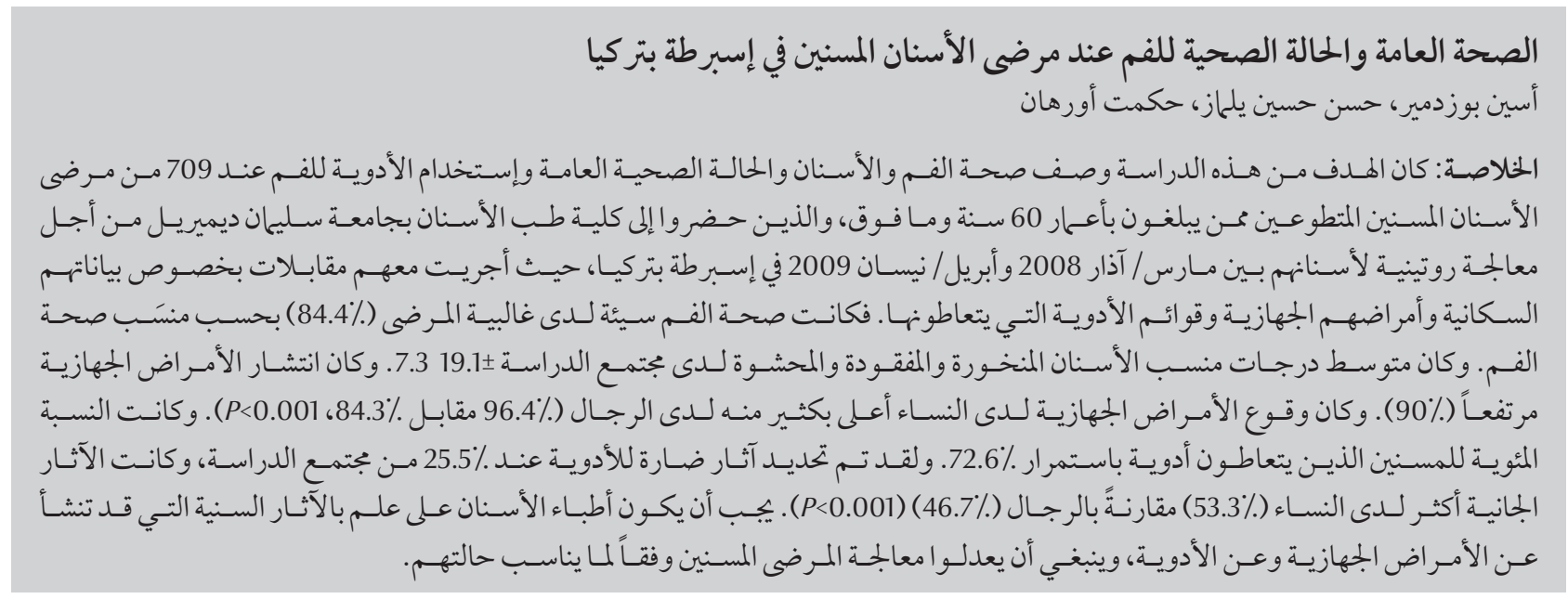

ABSTRACT The aim of this study was to describe the oral health, general health status and medication use of elderly dental patients 709 voluntary patients, aged 60 years and over, who attended Suleyman Demirel University Faculty of Dentistry for routine dental treatment between March 2008 and April 2009 in Isparta, Turkey, were interviewed for demographic data, systemic diseases, and lists of medications. The majority of the patients (84.4\%) had poor oral hygiene according to the Oral Hygiene Index (OHI). The mean level of the study population's decayed, missing, and filled teeth (DMFT) index score was $19.1 \pm 7.3$. The prevalence of systemic diseases was high (90\%). Women were affected by a significantly higher incidence of systemic diseases than men $(96.4 \%$ vs. $84.3 \% ; P<0.001)$. The percentage of the elderly taking medication regularly was $72.6 \%$. Drug adverse effects were determined in $25.5 \%$ of the study population, with more adverse effects observed in women (53.3\%) than men (46.7\%) $(P<0.001)$.Dentists must be aware of the dental implications that may arise from systemic diseases and medications and should properly modify elderly patients' treatment accordingly.

\section{État de santé générale et bucco-dentaire chez des patients dentaires âgés à Isparta, en Turquie}

RÉSUMÉ La présente étude avait pour objectif de décrire la santé bucco-dentaire de patients dentaires âgés, leur état de santé général et leur recours aux médicaments ; 709 patients volontaires, âgés de 60 ans et plus, qui avaient consulté à la Faculté de Dentisterie de l'Université de Suleyman Demirel pour des soins dentaires de routine entre mars 2008 et avril 2009 à Isparta, en Turquie, ont été interrogés pour obtenir des données démographiques, ainsi qu'au sujet des maladies systémiques et des listes de médicaments qui les concernaient. La majorité des patients $(84,4 \%)$ avaient une mauvaise hygiène bucco-dentaire selon l'indice d'hygiène buccale. Le niveau moyen de l'indice CAO (dent cariée, absente ou obturée) de la population étudiée était de 19,1 \pm 7,3. La prévalence des maladies systémiques était élevée (90\%). Les femmes étaient significativement plus affectées par les maladies systémiques que les hommes $(96,4 \%$ contre $84,3 \% ; p<0,001)$. Le pourcentage de personnes âgées prenant des médicaments sur une base régulière était de $72,6 \%$. Les effets secondaires provoqués par les médicaments ont été déterminés pour 25,5\% de la population étudiée, avec davantage d'effets secondaires observés chez les femmes $(53,3 \%)$ que chez les hommes $(46,7 \%)(p<0,001)$. Les dentistes doivent avoir connaissance des implications dentaires pouvant être causées par des maladies systémiques et des traitements médicamenteux, et devraient modifier les soins apportés aux personnes âgées en conséquence. 


\section{Introduction}

The world's population is aging. According to changes occurring in the age structure of the world population, the 20th century was a turning point in human history; the elderly population grew dramatically in the second half of the 20th century, and now the Turkish population structure is becoming similar to that of most developed European countries (1). Because the elderly population is increasing and the elderly have a longer life expectancy in most parts of the world, the number of elderly individuals who are admitted for treatment by dentists will increase in the future.

Oral epidemiological investigations report that most of the elderly around the world do not have adequate oral hygiene habits (2). Impaired health and medications can affect their oral health status and dental treatment. In addition to systemic diseases and medications, poor oral hygiene may be due to a lack of awareness regarding oral health and its importance as well as the inability to access oral health services for restorative care (3).

Elderly patients tend to have more systemic diseases and consume more medications than individuals in other age groups. Some systemic diseases and medications may influence oral health and/or dental treatment to some degree, and, conversely, dental treatment may have an influence on some systemic conditions (4). Therefore, it is important that dentists are aware of common medical conditions and associated medications that are used by the elderly. Dentists must also be aware of complications that may endanger the lives of elderly patients during dental treatment. Thus, taking a careful medical history before any dental procedure is crucial in order to provide appropriate dental care for these older patients.

The purpose of this study was to obtain information about elderly patients' general health status, medication use, side effects observed in the oral region due to the use of medicines, and oral hygiene applications. An additional goal was to investigate the relationship between the medical conditions and medications used as they relate to age and gender.

\section{Methods}

This research was approved by the ethics committee of the Suleyman Demirel University School of Medicine. Written informed consent was obtained from all of the participants. A total of 709 voluntary patients aged 60 years and over were included in the study.

The study population consisted of randomly selected elderly patients living in Isparta (a city in Turkey) admitted to department of oral diagnosis and maxillofacial radiology in Suleyman Demirel University Faculty of Dentistry with various dental complaints from March 2008 to April 2009. The volunteers were included in this study.

\section{Data Collection}

The data collection tool was an anamnesis form, which included various questions about patients' sociodemographic characteristics, general health status, medication use, side effects observed in the oral region due to the use of medicines, oral hygiene applications, and smoking or alcohol addictions.

All participants were interviewed by one investigator. For those participants who were poor historians, additional information was obtained from the individual's family members. Medical conditions were categorized systemically, and medications were categorized based on their therapeutic classifications.

\section{Clinical Examination}

Patients were examined in public clinic in faculty of dentistry. All examinations were performed by one examiner under artificial light and using a dental explorer, flat-surface mouth mirror, gauze, sponges, and compressed air. The number of natural teeth, calculus-plaque control, and decayed $/ \mathrm{missing} /$ filled teeth were evaluated using the Oral Hygiene Index (OHI) (Greene and Vermillion) and the decayed, missing, and filled teeth (DMFT) index (5).

Decayed teeth (with either cavities or no cavities) were diagnosed with the use of dental explorer and were scored as "D." Missing teeth were scored as "M" when the tooth was extracted due to caries, as judged by the examiner after interviewing. Even though the third molars were present in the mouth, they were excluded from evaluation in determining the number of lost teeth. Crowns and abutments were considered to be filled teeth. Oral hygiene was assessed via the $\mathrm{OHI}$, which has two components: the debris index and the calculus index. Both of these indices are based on numerical determination representing the amount of calculus and debris found on the surfaces of teeth. From each segment, the tooth with the highest score was used for calculating the individual index for that particular segment. The index for each patient was obtained by summing the indices for all six segments. The qualitative criteria of the index ranges from 0 to 6 ; the debris and calculus can be classified as excellent (0.0), good (0.1-1.2), regular (1.3-3.0), and weak (3.1-6.0).

The SPSS (Statistical Package for Social Sciences) for Windows 17.0 software was used for the statistical analysis of the data. A mean and standard deviation were used as descriptive statistics. Pearson's chi-square test and an independent $t$-test were used to test the differences in incidences and types of medical conditions and medications in relation to age and gender. The level of significance was set at 0.05 . 


\section{Results}

The study sample of 709 elderly patients included 375 (53\%) men and 334 (47\%) women. Participants were divided into three age groups: 60-64 years (36.4\%), 65-69 years (31.6\%), and $\geq 70$ years old ( $32 \%)$. The questionnaire revealed that $34.2 \%$ of the participants regularly brushed their teeth. The frequencies of tooth brushing were as follows: $55 \%$ brushed once, $38.1 \%$ brushed twice, and $6.9 \%$ brushed more than twice daily.

The majority of the elderly (84.4\%) had poor oral hygiene according to the OHI. There was no statistically significant difference between the genders in oral hygiene condition $(P=0.13)$. The study population's mean DMFT index score was $19.1 \pm 7.3$. The average numbers of missing and filled teeth were $14.3 \pm 7.8$ and $3.2 \pm 3.9$, respectively. The average number of missing teeth was greater for women $(15.4 \pm 7.7)$ than for men $(13.5 \pm 7.7 ; P=0.004)$. The edentulous population included $21.2 \%$ of participants $(26.7 \%$ were women and $16.2 \%$ were men; $P=0.001)$. The average number of remaining teeth in the mouth was 14.2 (15.1 in men and 12.9 in women).

The overall incidence of medical conditions was $90 \%$. The age group with the most systemic diseases was the 6064 age groups (see Table 1). There was not statically significant difference in the presence of systemic diseases according to age group $(P=0.67)$. Women were affected by a significantly higher incidence of systemic diseases than men $(P<0.001)$. Cardiovascular diseases found in $65 \%$ of the sample were often identified as a systemic disease group. The number of diseases was categorized as $0,1-3$, and 4+. Elderly patients most commonly reported the presence of $1-3$ diseases $(P<0.001$; see Table 1$)$.

Cardiovascular diseases, bone-joint disorders, respiratory diseases, and genitourinary disorders were more prevalent in the oldest age group ( $\geq 70$ years old; see Table 2).

Among cardiovascular diseases, hypertension was the most common disorder experienced by elderly patients (reported by $45.7 \%$ of the sample). Bone-joint disorders were found to be significantly more common in women than in men $(\mathrm{P}<0.001)$.

The most common disorder in the bone-joint disease group was osteoporosis, followed by osteoarthritis. Diabetes mellitus was the most common disorder among the endocrine diseases. The most common disorder in the respiratory disease group was chronic obstructive pulmonary disease (COPD). Table 3 shows the distribution of the most frequently diagnosed diseases in relation to gender according to systems.

Eighty-two percent of the elderly population reported taking medications, with an average of 3.3 drugs per person. Of those who took medication, $72.6 \%$ did on a regular basis. More women $(53.4 \%)$ than men $(46.6 \%)$ took medications regularly $(P=0.02)$. However, the average number of drugs taken did not increase as age increased.
With reference to age groups, the use of medications was not significantly different among the three age groups $(P=0.08)$. The incidence was $29.1 \%$ in the 60-64 group, $25.8 \%$ in the 65-69 group, and $27.9 \%$ in the 70 and older group.

When drug groups were evaluated according to age groups, it was determined that the incidence of cardiovascular drugs, drugs acting on the autonomous nervous system and the respiratory system, autacoids, and vitamins increased as age increased. Table 4 shows the distribution of drug groups according to age groups. There was no increase in the number of drugs as age increased. There was no statistically significant difference in terms of number of drugs among age groups $(P=0.19)$.

The four most prevalent drug groups were cardiovascular medications (36.5\%), endocrinology drugs (19.5\%), central nervous system drugs (13.6\%), and gastrointestinal drugs (9.1\%). These groups of drugs were commonly used by both women and men. It was detected that $25.5 \%$ of the study population reported side effects from drug use; side effects were experienced more often by women $(53.3 \%)$ than by men $(46.7 \%)(P<0.001)$. The drug groups causing the most side effects were antihypertensive drugs ( $81.6 \%)$, antidepressants (54.2\%), and drugs related to the endocrine system (insulin, oral antidiabetics, and glucagon; 45.5\%). The most common side effect was dry mouth (72.6\%). The second most common side effect observed in the oral

\begin{tabular}{|c|c|c|c|c|c|c|c|c|c|}
\hline \multirow{2}{*}{$\begin{array}{l}\text { Age group } \\
\text { (years) }\end{array}$} & \multicolumn{3}{|c|}{ With systemic disease } & \multicolumn{3}{|c|}{ Without systemic disease } & \multicolumn{3}{|c|}{ Number of diseases } \\
\hline & $\begin{array}{l}\text { Men } \\
n(\%)\end{array}$ & $\begin{array}{c}\text { Women } \\
n(\%)\end{array}$ & $\begin{array}{l}\text { Total } \\
n(\%)\end{array}$ & $\begin{array}{l}\text { Men } \\
n(\%)\end{array}$ & $\begin{array}{c}\text { Women } \\
n(\%)\end{array}$ & $\begin{array}{l}\text { Total } \\
n(\%)\end{array}$ & $\begin{array}{c}\text { No } \\
\text { Disease } \\
n(\%)\end{array}$ & $\begin{array}{c}1-3 \\
n(\%)\end{array}$ & $\begin{array}{c}4+ \\
n(\%)\end{array}$ \\
\hline $60-64$ & $109(15.4)$ & $21(17.1)$ & $230(32.4)$ & $21(3.0)$ & $7(1.0)$ & $28(3.9)$ & $32(4.5)$ & $180(25.4)$ & $46(6.5)$ \\
\hline $65-69$ & $100(14.1)$ & $98(13.8)$ & $198(27.9)$ & $21(3.0)$ & $5(0.7)$ & $26(3.7)$ & $28(3.9)$ & 139 (19.6) & $57(8)$ \\
\hline$\geq 70$ & $108(15.2)$ & $102(14.4)$ & $210(29.6)$ & $16(2.3)$ & $1(0.1)$ & $17(2.4)$ & $18(2.5)$ & $124(17.5)$ & $85(12)$ \\
\hline Total & $317(44.7)$ & $321(45.3)$ & $638(90.0)$ & $58(8.2)$ & $13(1.8)$ & $71(10.0)$ & $78(11)$ & $443(62.5)$ & $188(26.5)$ \\
\hline
\end{tabular}




\begin{tabular}{|c|c|c|c|c|}
\hline Disease/disorders & $\begin{array}{c}60-64 \\
n(\%)\end{array}$ & $\begin{array}{c}65-69 \\
n(\%)\end{array}$ & $\begin{array}{l}\geq 70 \\
n(\%)\end{array}$ & $\begin{array}{l}\chi^{2} / P \\
\text { value }\end{array}$ \\
\hline Cardiovascular disease & $150(32.4)$ & $152(32.8)$ & $161(34.8)$ & 0.008 \\
\hline Bone/joint disorders & $124(33.3)$ & $110(29.6)$ & $138(37.1)$ & 0.009 \\
\hline Endocrine disorders & $71(33.3)$ & $82(38.5)$ & $60(28.2)$ & 0.034 \\
\hline Respiratory diseases & $25(25.3)$ & $23(23.2)$ & 51 (51.5) & 0.000 \\
\hline Gastrointestinal disorders & $91(37.9)$ & $57(23.8)$ & $92(38.3)$ & 0.003 \\
\hline Neuropsychiatric disorders & $49(29.3)$ & $60(35.9)$ & $58(34.7)$ & 0.091 \\
\hline Hematologic disorders & $25(34.7)$ & $21(29.2)$ & $26(36.1)$ & 0.730 \\
\hline Skin diseases & $23(43.4)$ & $17(32.1)$ & $13(24.5)$ & 0.411 \\
\hline Genitourinary disorders & $34(29.8)$ & $33(28.9)$ & $47(41.2)$ & 0.064 \\
\hline
\end{tabular}

region due to the use of medicines was taste change (45.2\%). Lastly, 28.3\% of the study population and $30.1 \%$ of elderly patients who used drugs in particular had dry mouth complaints.

\section{Discussion}

Epidemiological investigations indicate that most of the elderly have insufficient oral hygiene practices. Because elderly people have not effectively controlled microbial dental plaque, they have poor oral hygiene. The percentage of older people performing regular oral hygiene substantially varies among countries. For instance, the range is different in Africa ( $8 \%-42 \%)$, Southeast Asia (32\%-84\%), and Europe (22\%-93\%) based on the present reports given by those countries (2). In this study, the percentage of the elderly who regularly brushed their teeth was $34.2 \%$, and the majority of the elderly (84.4\%) had poor oral hygiene according to the $\mathrm{OHI}$.

The rate of edentulousness in older populations has often been used as an indicator of oral health. The prevalence of edentulism decreased from 1988 (75\%) to 2004 (48\%) in 65-74-yearolds in Turkey $(6,7)$. In this study, the percentage of the edentulous population was $21.2 \% ; 26.7 \%$ of women and $16.2 \%$ of men were edentulous. Although women have reported a higher prevalence of edentulism in some studies, this difference was not significant in the current study $(8,9)$. On the contrary, there was a statistically significant difference in the edentulousness rates between genders in this study; this has also been reported in several other studies $(10,11)$.
The DMFT value was 19.1 in this study. This value is lower than results from other studies conducted in Turkey and many developing countries. This may be due to a decreasing tendency in the prevalence of edentulousness in older populations (12-16).

The prevalence of chronic diseases increases with advancing age. Worldwide, the prevalence of chronic diseases ranges from $56 \%$ to $83 \%$ in the elderly (17). The prevalence of chronic diseases in the elderly Turkish population is also high; chronic disease incidence ranges from $57 \%$ to $89 \%$ in elderly residents of various rest homes in Turkey $(18,19)$.

According to a study conducted in Turkey, it was determined that $90 \%$ of people over the age of 65 have one chronic disease, $35 \%$ have two chronic diseases, $23 \%$ have three chronic diseases, and $15 \%$ have four or more chronic

Table 3 Distribution of the most frequently diagnosed diseases in relation to gender according to systems.

\begin{tabular}{lll} 
& \multicolumn{1}{c}{ The most frequently diagnosed diseases (\%) } \\
Cardiovascular disease & \multicolumn{1}{c}{ Men } & \multicolumn{1}{c}{ Women } \\
Bone/joint disorders & Hypertension (80.8) & Hypertension (81.9) \\
Endocrine disorders & Osteoarthritis (42.4) & Osteoporosis (63.5) \\
Respiratory diseases & Diabetes Mellitus (88.8) & Diabetes Mellitus (60.9) \\
Gastrointestinal disorders & COPD (74.1) & Asthma (53.7) \\
Neuropsychiatric disorders & Peptic ulcer (60) & Peptic ulcer (64.1) \\
Hematologic disorders & Depression (33.3) & Depression (38.6) \\
Skin diseases & Anemia (36.8) & Anemia (56.6) \\
Genitourinary disorders & Dermatitis (27.3) & Onychomycosis (30) \\
\hline
\end{tabular}




\begin{tabular}{|c|c|c|c|}
\hline \multirow[t]{2}{*}{ Drug groups } & \multicolumn{3}{|c|}{ Age groups (years) } \\
\hline & $\begin{array}{c}60-64 \\
n(\%)\end{array}$ & $\begin{array}{l}65-69 \\
n(\%)\end{array}$ & $\begin{array}{l}\geq 70 \\
n(\%)\end{array}$ \\
\hline Cardiovascular drugs & $121(68.8)$ & $126(78.3)$ & $130(73)$ \\
\hline Drugs acting on balance of water, salt, acid-base & $1(0.6)$ & 0 & $5(2.8)$ \\
\hline Drugs acting on respiratory system & $14(8.0)$ & $12(7.5)$ & $25(14.0)$ \\
\hline Drugs acting on central nervous system & $45(25.6)$ & $48(29.8)$ & $48(27.0)$ \\
\hline Drugs acting on autonomous nervous system & $15(8.5)$ & $17(10.6)$ & $22(12.4)$ \\
\hline Endocrinologic drugs & $63(35.8)$ & $71(44.1)$ & $67(37.6)$ \\
\hline Autacoids & $3(1.7)$ & $6(3.7)$ & $8(4.5)$ \\
\hline Vitamins & $6(3.4)$ & $9(5.6)$ & $12(6.7)$ \\
\hline Blood and blood forming agents & $4(2.3)$ & 0 & $4(2.2)$ \\
\hline Gastrointestinal drugs & $34(19.3)$ & $24(14.9)$ & $36(20.2)$ \\
\hline Ophthalmologic preparations & $14(8.0)$ & $11(6.8)$ & $10(5.6)$ \\
\hline Antibiotics and the other chemotherapeutic & $6(3.4)$ & $2(1.2)$ & 0 \\
\hline $\begin{array}{l}\text { The other drugs (protein, alpha lipoic acid, antioxidant, } \\
\text { phelebotonic drugs, herbal products) }\end{array}$ & $3(1.7)$ & $3(1.8)$ & $8(4.5)$ \\
\hline Total & $176(34.2)$ & $161(31.3)$ & $178(34.6)$ \\
\hline
\end{tabular}

diseases (20). In the current study, 90\% of the elderly had one or more systemic diseases, $23.4 \%$ had two chronic diseases, $22.8 \%$ had three chronic diseases, and $26.7 \%$ had four or more chronic diseases.

When the relationship between chronic diseases and gender was examined in various studies, it was found that the incidence of chronic diseases is significantly higher in women $(17,21)$. In this study, the incidence of chronic diseases was found to be $96.4 \%$ in women and $84.3 \%$ in men. This may be due to the rapid decline in physiological functions in women after menopause $(22,23)$.

It is known that aging is a risk factor for cardiovascular diseases, and the incidence of cardiovascular system pathologies, such as hypertension, cerebrovascular disease, coronary artery disease, and heart failure, increases with age. Diseases of the cardiovascular system were the most commonly reported disease group in the elderly in Turkey (6), just as in various studies worldwide (17). Cardiovascular diseases were the most commonly reported disease group in the current study as well. It has been reported in various studies (4) that cardiovascular diseases occur more frequently in women; this study showed these results as well.

Increases in blood pressure (BP), particularly systolic BP, have traditionally been considered to be a normal or physiologic component of the aging process. However, it is now clear that elevated BP, particularly systolic BP, represents a pathophysiologic manifestation of altered cardiovascular physiology and structure (24). It has been determined that hypertension is the most prevalent cardiovascular disorder in the elderly population in Turkey and also worldwide $(17,25)$. In the current study, hypertension was the most prevalent cardiovascular disorder. This is similar to various studies in Turkey that have reported incidence ranges from $30 \%$ to $62 \%$ (18). The prevalence of hypertension was $53.2 \%$ in the current study, with women showing a higher prevalence than men. This is believed to be the case because obesity is more common in women in Turkey (26).

It is known that the incidence of bone-joint system diseases increases with aging. The incidence of bone-joint system diseases was higher in the 70 and older group in the participants in the current study. Female gender is one of the risk factors for bone-joint diseases; some studies have reported that women have bone-joint diseases more frequently than men (17). This study's results indicated that bone-joint disorders affect women twice as often as men. Due to loss of estrogen during menopause, women have a fourfold greater risk than men for developing osteoporosis $(22,23)$. Osteoporosis was found to be the most common bonejoint disorder among elderly women in this study.

Due to changes in the gastrointestinal tract and the use of multiple medications, the incidence of gastrointestinal tract diseases increases in the elderly. Because of the high prevalence of nonsteroidal anti-inflammatory drug use and an increase in Helicobacter pylori in the elderly, the incidence of peptic ulcers also increases with aging. It was found that the prevalence of Helicobacter pylori was $90 \%$ in patients over 60 years old in one study (20). In the current investigation, peptic ulcer was 
the most common gastrointestinal tract disease in both men and women.

Glucose tolerance decreases and serum insulin levels rise with age as a result of a decrease in the insulin sensitivity of cells. The prevalence of diabetes mellitus increases with age, and it peaks at 60-69 years old (20). The prevalence of diabetes is 8.8 times higher in the 65-74 age group than in the 20-44 age group. In a study by Onat et al. (27), while the prevalence of diabetes was $20 \%$ in $60-69$ year-olds, it was $15 \%$ in the over-70 age group. In the current study, diabetes mellitus was identified as the most common endocrine system disorder in both men and women. The prevalence of endocrine system disorders was higher in the 60-69 age group than in those over 70 years old.

COPD, one of the pulmonary system diseases, is one of the main causes of chronic morbidity and mortality worldwide, and it is the fourth leading cause of death worldwide. It was determined that approximately $16 \%$ of elderly persons over the age of 65 had COPD in one study (20). COPD usually affects the elderly more often. In the current study, the prevalence of pulmonary tract diseases was higher in the 70 and above age group than in the other age groups. It was reported that the prevalence of COPD was $9.1 \%$ in Spain, $8.4 \%$ in Greece, and $11.4 \%$ in Europe. There are about 3 million COPD patients in Turkey. The prevalence of COPD is higher in men than in women (28). In this study, COPD was the most common pulmonary system disease among elderly men. This may be due to cigarette use, which is a major risk factor for COPD and is more common in men.

Depression is more common in the elderly than in the general population, and it is an important public health problem. The reported incidence of depression in the elderly ranges from $1 \%$ to $60 \%$ in various studies; this varies according to the studies' methods and goals (29). It has also been found that the prevalence of depression ranges from $1 \%$ to $69 \%$ in the elderly living in various rest homes and in their own homes in Turkey (30,31). Depression was identified as the most common neuropsychiatric disease in both men and women in the current study.

Testosterone and age are the two most important factors in the formation of benign prostate hypertrophy (BPH). Therefore, detection of $\mathrm{BPH}$ in elderly male patients is a normal condition. BPH can be identified histopathologically in $80 \%$ of men over the age of 60 (20). In this study, BPH was determined to be the most common genitourinary system disease among elderly men.

There is a trend toward increased use of medications and an increase in systemic diseases in the elderly (17). It has been found that the prevalence of medication use in the Turkish elderly ranges from $45.2 \%$ to $84.7 \%(18,19)$. In this study, it was determined that the prevalence of medication use was $82.8 \%$, with women $(90.8 \%)$ taking medications more regularly than men (85.4\%). The pattern of medication use in the current study is similar to other reports in Turkey and worldwide (17, 32,33). Cardiovascular agents are the most common group of drugs taken by the elderly.

Since the number of chronic medical conditions and use of medications increases with age, the prevalence of medication-related oral problems is high in the elderly. In this study, the most common medication-related oral problem was dry mouth. However, a large number of diseases and medications are known to interfere with salivary gland functioning. It was reported by Zavras et. al. (34) that older individuals were almost three times more likely to report dry mouth, and patients taking one or more drugs were more than twice as likely to do so compared with medication-free patients (35).

A limitation of this study is the relatively small sample size, which may not be representative of the general elderly population, as we obtained a convenient sample.

\section{Conclusion}

Results of the current investigation support the findings of previous studies regarding the reported high prevalence of medical conditions in and medications used by the elderly. It was found that the prevalence of systemic diseases is quite high (90\%).

As medical history taking is importantin this agegroup, medical anamnesis should include a health questionnaire, an interview, and obtaining copies of treatment records from the individual's physicians and careful analysis of all the drugs being taken. Because the elderly are almost always on long-term drug therapy frequently involving multiple drugs, dentists must be knowledgeable as to the nature and side effects of drugs taken by their older patients and of the need to modify the management of patient treatment as appropriate.

\section{Acknowledgements}

On behalf of all authors, the corresponding author states that there is no conflict of interest. There is no contribution of any funding organization in this study.

Funding: None.

Competing interests: None declared. 
1. Radfar L, Suresh L. Medical profile of a dental school patient population. J Dent Educ. 2007 May;71(5):682-6. PMID:17493977

2. Petersen PE, Kandelman D, Arpin S, Ogawa H. Global oral health of older people-call for public health action. Community Dent Health. 2010 Dec;27(4) Suppl 2:257-67. PMID:21313969

3. Skorupka W, Zurek K, Kokot T, Nowakowska-Zajdel E, Fatyga E, Niedworok E, et al. Assessment of oral hygiene in adults. Cent Eur J Public Health. 2012 Sep;20(3):233-6. PMID:23285527

4. Loesche WJ, Schork A, Terpenning MS, Chen YM, Dominguez $\mathrm{BL}$, Grossman N. Assessing the relationship between dental disease and coronary heart disease in elderly U.S. veterans. J Am Dent Assoc. 1998 Mar;129(3):301-11. PMID:9529805

5. El Osta N, Tubert-Jeannin S, Bou Abboud Naaman N, Hennequin $\mathrm{M}$, El Osta L, Geahchan N. Oral and General Health Indicators for Lebanese Elderly in Oral surveys: Review Article. IAJD. 2012;3:54-61.

6. Saydam G, Oktay I, Möller I. Oral Health Status Analysis. Ankara: WHO European Region-Ministry of Health; 1990.

7. Gökalp SG, Doğan BG, Tekçiçek MT, Berberoğlu A, Unlüer S. National survey of oral health status of children and adults in Turkey. Community Dent Health. 2010 Mar;27(1):12-7. PMID:20426255

8. Suominen-Taipale AL, Alanen P, Helenius H, Nordblad A, Uutela A. Edentulism among Finnish adults of working age, 1978-1997. Community Dent Oral Epidemiol. 1999 Oct;27(5):353-65. PMID:10503796

9. Fure S, Zickert I. Incidence of tooth loss and dental caries in 60-, 70- and 80-year-old Swedish individuals. Community Dent Oral Epidemiol. 1997 Apr;25(2):137-42. PMID:9181287

10. Haikola B, Oikarinen K, Söderholm AL, Remes-Lyly T, Sipilä K. Prevalence of edentulousness and related factors among elderly Finns. J Oral Rehabil. 2008 Nov;35(11):827-35. PMID:18482342

11. Eustaquio-Raga MV, Montiel-Company JM, Almerich-Silla JM. Factors associated with edentulousness in an elderly population in Valencia (Spain). Gac Sanit. 2013 Mar-Apr;27(2):123-7. PMID:22591636

12. Gokalp S, Guciz Dogan B. Türkiye Ağız-Diş, Sağlığı Profili 2004, [The Oral Health Profile of Turkey 2004].2. Basım. Hacettepe Üniversitesi Yayınları, Ankara, ISBN: 978-975-491-2708, 2009 pp. 29-30 [in Turkish].

13. Unlüer S, Gökalp S, Doğan BG. Oral health status of the elderly in a residential home in Turkey. Gerodontology. 2007 Mar;24(1):22-9. PMID:17302927

14. Namal N, Can G, Vehid S, Koksal S, Kaypmaz A. Dental health status and risk factors for dental caries in adults in Istanbul, Turkey. East Mediterr Health J. 2008 Jan-Feb;14(1):110-8. PMID:18557458

15. Gaszynska E, Szatko F, Godala M, Gaszynski T. Oral health status, dental treatment needs, and barriers to dental care of elderly care home residents in Lodz, Poland. Clin Interv Aging. 201409 25;9:1637-44. PMID:25284997

16. Rihs L B, da Silva D D, de Sousa Mda L. (2009) Dental caries in an elderly population in Brazil. J Appl Oral Sci 2009;17[1]:812-30.2.

17. Jainkittivong A, Aneksuk V, Langlais RP. Medical health and medication use in elderly dental patients. J Contemp Dent Pract. 200402 15;5(1):31-41. PMID:14973558
18. Altintas H, Attila S, Sevencan F, Akçalar S, Sevim Y, Solak OS, et al. The Screening of Depression Symptoms Of The Elderly Living In A Residential Home In Ankara. TAF Prev Med Bull. 2006;5(5):332-42. [Turkish.]

19. Öğüt $S$, Polat $M$, Orhan H. Isparta ve Burdur Huzurevlerinde Kalan Yașılıarın Sosyodemografik Durumları ve Beslenme Tercihleri. Turkish Journal of Geriatrics. 2008;11:82-7.

20. Gökçe-Kutsal Y, Aslan D. Temel Geriatri. Ankara: Güneş Kitabevleri; 2007.

21. Canbaz S, Sunter AT, Dabak S, Peksen Y. The Prevalence of Chronic Diseases and Quality of Life in Elderly People in Samsun. Turk J Med Sci. 2003;33:335-40.

22. Lobo RA, Davis SR, De Villiers TJ, Gompel A, Henderson VW, Hodis HN, et al. Prevention of diseases after menopause. Climacteric. 2014 Oct;17(5):540-56. PMID:24969415

23. Menopause: Complications. The Mayo Clinic Health Information website. Available at:http://www.mayoclinic.com/ health/menopause/DS00119/DSECTION=complicatios. Accessed February 25, 2016.

24. Sander GE. High blood pressure in the geriatric population: treatment considerations. Am J Geriatr Cardiol. 2002 JulAug;11(4):223-32. PMID:12091771

25. Altıparmak S, Karadeniz G, Altıparmak O. Yaşlılarda hipertansiyon prevalansı: Manisa Örneği. Turkish Journal of Geriatrics. 2006;9:197-201.

26. Erem C. Prevalence of Overweight and Obesity in Turkey. IJC Metab Endocr. 2015;8:38-41.

27. Onat A, Hergenç G, Uyarel H, Can G, Ozhan H. Prevalence, incidence, predictors and outcome of type 2 diabetes in Turkey. Anadolu Kardiyol Derg. 2006 Dec;6(4):314-21. PMID:17162275

28. de Marco R, Accordini S, Cerveri I, Corsico A, Sunyer J, Neukirch F, et al.; European Community Respiratory Health Survey Study Group. An international survey of chronic obstructive pulmonary disease in young adults according to GOLD stages. Thorax. 2004 Feb;59(2):120-5. PMID:14760151

29. Tamam L, Öner S. Yaşılııı Çă̆ı Depresyonları. Demans Dergisi. 2001;1:50-60.

30. Bekaroğlu M, Uluutku N, Tanriöver S, Kirpinar I. Depression in an elderly population in Turkey. Acta Psychiatr Scand. 1991 Aug;84(2):174-8. PMID:1950613

31. Kulaksızoğlu IB, Gürvit H, Polat A, Harmanci H, Cakir S, Hanagasi $\mathrm{H}$, et al. Unrecognized depression in communitydwelling elderly persons in Istanbul. Int Psychogeriatr. 2005 Jun;17(2):303-12. PMID:16050438

32. Diker J. Diseases and drug use in elderly over 65 years in the Korfez Health Center 6 as well as in the one at Yuzbasilar in the Province of Kocaeli. Turkish Journal of Geriatrics. 2000;3:91-7.

33. Dundar N, Ilhan Kal B. Oral mucosal conditions and risk factors among elderly in a Turkish school of dentistry. Gerontology. 2007;53(3):165-72. PMID:17202819

34. Zavras Al, Rosenberg GE, Danielson JD, Cartsos VM. Adverse drug and device reactions in the oral cavity: surveillance and reporting. J Am Dent Assoc. 2013 Sep;144(9):1014-21. PMID:23989840

35. Lynge Pedersen AM, Nauntofte B, Smidt D, Torpet LA. Oral mucosal lesions in older people: relation to salivary secretion, systemic diseases and medications. Oral Dis. 2015 Sep;21(6):721-9. PMID:25754744 